\title{
CYBERBULLYING AND PUBLIC POLICY: AN EVOLUTIONARY PERSPECTIVE
}

\author{
CHRIS BERG·
}

\section{Contents}

I Conceptualising Bullying and Cyberbullying

II Cyberbullying and Public Policy

III Cyberbullying and Social Learning .

Cyberbullying is a topic of increasing sociological, legal and educational focus. There has been a great deal of media interest in the prevalence and harm caused by cyberbullying. Likewise, there has also been substantial public policy interest in cyberbullying. In 2015 the Australian government passed the Enhancing Online Safety for Children Act 2015 (Cth), which among other things established a Children's eSafety Commissioner with the power to hear complaints and require large social media sites to take down content deemed harmful to children. This was done in the light of New Zealand's Harmful Digital Communications Bill 2013, which also established a complaints based system for handling harmful digital communications. ${ }^{1}$

Peta Spyrou's primary article is a valuable contribution to the discussion. By redirecting the question from the legal liabilities of schools to the issue of how to foster school and parent engagement, it underlines the point that the problem of cyberbullying is not fundamentally a legal problem but a social one. Bullying needs to be countered by social arrangements that involve parents, teachers and the affected children.

In this comment I will make three points in an attempt to extend and enhance the conclusions provided by the paper. First, cyberbullying is not a new form

BA (Hons) (University of Melbourne); PhD candidate at RMIT University, Melbourne; Senior Fellow at the Institute of Public Affairs, Melbourne. I would like to thank Jason Potts and Simon Breheny for their comments on this paper.

Department of Communications, Enhancing Online Safety for Children: Public Consultation on Key Election Commitments, (Australian Government, 2014). 
of social activity but rather one new form of bullying. Second, how we conceptualise cyberbullying in relation to traditional bullying will affect our policy approach. ${ }^{2}$ Such a subordinate categorisation helps us to direct the possible policy and social responses away from technological or legal responses, which focus on the characteristics of new technologies, and towards the relationships of children in as much as out of school. It also helps to avoid a false sense that by targeting specific forms of expression the bully problem is being tackled. Finally, this approach has the advantage of clarifying the costs of anti-cyberbullying policies, and underlines the importance of respecting the rights of children both to be protected from bullying as well as to develop their identities.

\section{CONCEPTUALISING BULlying AND CYBERBULlying}

The primary article is correct to identify the substantial prevalence of cyberbullying. However, for all the policy attention it has received, cyberbullying is 'substantially less prevalent' than traditional bullying. ${ }^{3}$ Cyberbullies tend to be traditional bullies and cyberbullying victims also tend to be victims of traditional bullying. ' $[\mathrm{H}]$ ardly any students are exclusively cybervictims'. ${ }^{5}$ It makes sense to look at cyberbullying as merely an aspect of the general bullying problem, rather than a discrete activity. Policies that approach cyberbullying in isolation from what happens in the school ground are unlikely to be effective. It might be objected that cyberbullying deserves

Sheri Bauman, 'Cyberbullying: What Does Research Tell Us?' (2013) 52(4) Theory Into Practice 249.

3 Peter K Smith et al, 'Cyberbullying: Its Nature and Impact in Secondary School Pupils' (2008) 49(4) Journal of Child Psychology and Psychiatry 376, 383; See also Robert Slonje and Peter K Smith, 'Cyberbullying: Another Main Type of Bullying?' (2008) 49 Scandinavian Journal of Psychology 147, 150; Petra Gradinger, Dagmar Strohmeier and Christiane Spiel, 'Traditional Bullying and Cyberbullying: Identification of Risk Groups for Adjustment Problems' (2009) 217(4) Zeitschrift fur Psychologie / Journal of Psychology 205, 211; Dan Olweus, School Bullying: Development and Current Status, (Paper presented at American Psychological Association's 120th Annual Convention, Orange County, $\begin{array}{llll}\text { Florida, } & 4 & \text { August } & \text { 2012) }\end{array}$ $<$ http://www.apa.org/news/press/releases/2012/08/cyberbullying.aspx>; Georges Steffgen and Andreas König, 'Cyber Bullying: The Role of Traditional Bullying and Empathy' in Bartolomeo Sapeo et al (eds), The Good, the Bad and the Challenging: Conference Proceedings (Vol II) (2009). (Paper presented at the conference, Copenhagen, Denmark, 1315 May 2009)

$<$ http://scholar.googleusercontent.com/scholar?q=cache:rPHpozE0yBkJ:scholar.google.com /\&hl=en\&as_sdt $=0,5>$.

4 Steffgen and König, 'Cyber Bullying' above n 3.

5 Gradinger et al, 'Traditional Bullying and Cyberbullying' above n 3, 212. 
special policy attention because it is experienced as a worse form of bullying by bully victims. But this is not a settled question. Some victims experience cyberbullying as less harmful than traditional bullying, because they can control their exposure to the bullying through their electronic devices. They can ignore bullying online in a way that they cannot ignore a face-to-face encounter. ${ }^{6}$ Victims particularly focus on the attributes of publicness and anonymity as primary determinants of bullying severity. ${ }^{7}$ Neither publicness or anonymity are unique to cyberbullying.

Furthermore, it is true that cyberbullying can be 'covert', as the primary article points out, but covert and subtle actions have always formed a part of traditional bullying. Researchers distinguish between physical bullying, verbal bullying, indirect bullying (that is, the spreading of rumours) and relational bullying. This latter variation consists of the manipulation of social relationships in order to cause harm to the victim. ${ }^{8}$ One common example is social exclusion or 'shunning'. Some researchers have raised the possibility that as school anti-bullying policies become more detailed and formal, bullies are moving into harder to detect forms of bullying. ${ }^{9}$

\section{Cyberbullying And Public Policy}

What does this mean for cyberbullying policy? At a first pass, it suggests that legal approaches focusing on technology are unlikely to be successful. For instance, the Australian government's Children's eSafety Commissioner has the power to issue content takedown notices to large social media websites. But given that victims of cyberbullying tend also to be victims of traditional bullying, to focus on overtly harmful social media content is to focus on a narrow slice of the problem rather than its totality. Acting on social media content through the government's scheme might offer guardians a false sense that they have relieved a child's broader set of bullying problems.

6 Smith et al, 'Cyberbullying: Its Nature and Impact in Secondary School Pupils' above n 3, 377.

7 Fabio Sticca and Sonja Perren, 'Is Cyberbullying Worse Than Traditional Bullying? Examining the Differential Roles of Medium, Publicity, and Anonymity for the Perceived Severity of Bullying' (2013) 42(5) Journal of Youth and Adolescence 739, 746.

8 Nicki R Crick and Jennifer K Grotpeter, 'Relational Aggression, Gender, and SocialPsychological Adjustment' (1995) 66(3) Child Development 710, 720.

9 Sarah Woods and Dieter Wolke, 'Does the Content of Anti-Bullying Policies Inform Us About the Prevalence of Direct and Relational Bullying Behaviour in Primary Schools?' (2003) 23(4) Educational Psychology 381, 396, 398. 
More importantly, however, the boundaries of bullying are not clear. The researcher danah boyd emphasises the point that much activity is falsely and unhelpfully categorised as bullying. ${ }^{10}$ For instance, press reports often characterise as bullying, activity better described as stalking and assault criminal acts for which there are clear legal remedies and present few conceptual or policy challenges. On the other side of the coin, boyd notes that the policy attention given to bullying has meant that a wide variety of interpersonal conflict is now being incorrectly described as bullying. Compressing such conflict into the category of bullying implies the existence of victims and aggressors; it can also lead to an incorrect assessment of the situation that demands punishment of wrongdoing, which might be harmful for both parties to the conflict. Furthermore, to describe a conflict as 'bullying' is to push that relationship into the scope of the now highly refined anti-bullying intervention policies, perhaps denying children the opportunity to learn how to navigate interpersonal conflict themselves. Intervention by adults is not always the ideal resolution for conflicts between children.

\section{Cyberbullying AND SOCIAL LEARNING}

The language that children use to describe conflicts reveals the complexities of their interpersonal relationships. For example, children distinguish between 'drama', 'pranks', 'meanness', and 'teasing'. Through this language we have a window into a highly nuanced social order. The nuances of that social order are quite opaque to outsiders. This is important for two reasons. First, interventions by adults may not be able to penetrate the complex relationships that have formed, and a lack of understanding about those complexities may lead to suboptimal outcomes. It may be that the spectrum of bullying behaviour where anti-bullying intervention can assist is quite narrow. Stalking, assault and harassment are too serious to be dealt with by anti-bullying policies and 'drama' is too complex and opaque.

Second, evolutionary economists emphasise the process whereby individuals adapt to change through learning and experimentation. ${ }^{11}$ Interventions aimed at preventing minor instances of what policymakers and guardians see as

danah boyd, It's Complicated: The Social Lives of Networked Teens (Yale University Press, 2014).

11 Kenneth E Boulding, 'What Is Evolutionary Economics?' (1991) 1(1) Journal of Evolutionary Economics 9, 12; Drew Fudenberg and David K Levine, The Theory of Learning in Games (MIT Press, 1998); Giovanni Dosi and Richard R Nelson, 'An Introduction to Evolutionary Theories in Economics' (1994) 4(3) Journal of Evolutionary Economics 153, 169. 
'bullying' could prevent paths of social learning. ${ }^{12}$ Serious bullying can hinder development by traumatising a student's physical and mental health. However, as Ken Rigby notes, this development relationship is not necessarily linear. A student's adaptation to bullying by, for example, retreating to the school library, might have beneficial academic consequences in the long run. ${ }^{13}$ There appears to be a wide lacuna for research into the schoolyard as an adaptive system where 'drama' fosters development, perhaps drawing on the posttraumatic growth literature. ${ }^{14}$ Horwitz argues for the importance of unsupervised childhood play in developing the skills of cooperation and informal rule-making. ${ }^{15}$ None of this would, of course, preclude intervention in the case of serious bullying - and certainly not in the case of criminal acts sometimes described as bullying — but it should awaken us to the complexity of interpersonal relationships and conflicts described by danah boyd. ${ }^{16}$ Children need to be seen as agents in a complicated social system who can, and do, make decisions that affect the system.

To be more concrete, I have previously criticised the Australian government's cyberbullying proposals on the grounds that the mechanism whereby a government agency requires social media sites to remove content deemed 'harmful' is a violation of the principle of freedom of speech. ${ }^{17}$ In his classic defence of the right to free speech, John Stuart Mill based his argument on the role that speech and ideas play in intellectual development. ${ }^{18}$ Social media websites play a powerful and important role in identity

12 A similar point is made in the context of 'libertarian paternalism' by Martin Binder, 'Should Evolutionary Economists Embrace Libertarian Paternalism?' (2014) 24(3) Journal of Evolutionary Economics 515, 532.

13 Ken Rigby, 'What Harm Does Bullying Do?' (Paper presented at the conference on Children and Crime: Victims and Offenders, Australian Institute of Criminology, Brisbane, 17-18 June 1999).

14 Aaron Jarden, 'Post-Traumatic Growth: An Introduction and Review' (2009) Autumn, New Zealand Clinical Psychologist,

$<$ http://www.aaronjarden.com/uploads/3/8/0/4/3804146/2009_-_posttraumatic_growth__an_introduction_and_review.pdf $>$.

15 Stephen Horwitz, 'Cooperation over Coercion: The Importance of Unsupervised Childhood Play for Democracy and Liberalism (2015) 3(1) Cosmos +Taxis 3, 16.

16 boyd, above $\mathrm{n} 10$.

17 Chris Berg and Simon Breheny, 'A Social Problem, Not a Technological Problem: Bullying, Cyberbullying and Public Policy’ (Institute of Public Affairs, August 2014). Note that the legislation brought to parliament provided for a much higher threshold than was originally proposed; s 5(1)(b)(ii) of the Enhancing Online Safety for Children Act 2015 (Cth) now limits this power to material that would have the effect of 'seriously threatening, seriously intimidating, seriously harassing or seriously humiliating' an Australian child.

18 John Stuart Mill, On Liberty (J W Parker and Son, 1859). 
development and relationship construction and mediation. ${ }^{19}$ While we should not demur from understanding the risks of online engagement, neither should we neglect to recognise the enormous developmental possibilities provided by technological innovation. The reluctance to mention bullying victimisation to adults for fear of having their electronic devices confiscated attests to the centrality of online activity to a child's identity.

Szoka and Thierer make the case that an approach to cyberbullying that focuses on education is likely to be more effective than one which takes as its approach regulation and control. ${ }^{20}$ Victims of bullying need the support of teachers, parents and schools. But most of all they need knowledge and tools with which they can navigate the complicated interpersonal relationships they will face at school, online, and in the future.

19 danah boyd, 'Why Youth (Heart) Social Network Sites: The Role of Networked Publics in Teenage Social Life' in David Buckingham (ed), Youth, Identity, and Digital Media, The John D and Catherine T MacArthur Foundation Series on Digital Media and Learning (MIT Press, 2007).

20 Berin Szoka and Adam D Thierer, 'Cyberbullying Legislation: Why Education Is Preferable to Regulation' (The Progress and Freedom Foundation, 2009) <http://www.pff.org/issuespubs/pops/2009/pop16.12-cyberbullying-education-better-than-regulation.pdf $>$. 